\title{
Kreftrisiko blant norske papir- og cellulosearbeidere
}

\author{
Hilde Langseth \\ Kreftregisteret, Institute of population-based cancer research \\ Telefon: 23333911 Telefax: 22451370 E-post: hilde.langseth@kreftregisteret.no
}

\section{ENGLISH SUMMARY}

Langseth H. Cancer risk in Norwegian pulp and paper workers. Nor J Epidemiol 2001; 11 (2): 187-192.

Results from a historical prospective cohort study on Norwegian pulp and paper workers showed a significant increase in risk of lung cancer, pleural mesothelioma, colon cancer and malignant melanomas among men, compared to the Norwegian population. The risk of lung cancer was highest among sulphite mill workers. The risk of pleural mesothelioma was highest among maintenance workers with asbestos exposure. Most of the increased risk in lung cancer can be explained by a combination of smoking habits and asbestos use, although an effect of other work-related exposures (sulfur and chloride compounds, wood dust) cannot be excluded. Among the female part of the cohort we found a significant excess in risk of ovarian cancer. The risk was highest among those younger than 55 years, and mostly among those working in paper departments. Relatively little is known about the causes of ovarian cancer, but it is however known that $5-7 \%$ can be explained by hereditary factors. Furthermore, fertility pattern plays a role. Asbestos and talc, which both have been used in the pulp and paper industry, are occupational and environmental agents, discussed as possible carcinogens for ovarian cancer.

\section{INTRODUKSJON}

Papir- og celluloseindustrien er en svært gammel industri i Norge, og den første kjemiske cellulosefabrikken åpnet i 1870, mens produksjonen av papir startet i 1890. Tremasse og papir har tradisjonelt blitt fremstilt gjennom to kjemiske prosesser kalt sulfitt og sulfatprosessen, samt en mekanisk prosess. Svovelforbindelser (svoveldioksid, hydrogensulfid, organiske sulfider, merkaptaner), klor og klorforbindelser er potensielle eksponeringer i denne industrien, i tillegg til karsinogener som asbest, trestøv og formaldehyd. En rekke andre biologisk aktive substanser som papirstøv, polyklorinerte bifenyler (PCB), fargestoffer, mikrober og talkum har også vært karakterisert i arbeidsatmosfæren.

En rekke internasjonale studier har kartlagt kreftrisiko, og en økt risiko for lungekreft, brysthinnekreft, kreft i fordøyelsesorganer og lymfe/bloddannende organer har vært assosiert med eksponeringer i denne industrien. På avdelingsnivå har lungekreftrisikoen spesielt vært knyttet til ansettelser i sulfittavdelinger $(1,2)$ sulfatavdelinger $(3)$, ansatte eksponert for organiske klorforbindelser (4), og blant ansatte i papir og papp-produksjon (5). Videre har vedlikeholdsarbeidere vist økt risiko for lungekreft knyttet til eksponering for asbest (6) og trestøv (7). Andre studier har imidlertid ikke vist økning i lungekreftrisiko (8-10).
Bruken av asbest har vært assosiert med økt risiko for brysthinnekreft blant papir- og cellulosearbeidere. Asbest har vært brukt i relativt store mengder som isolasjonsmateriale i syretanker, luftekanaler, rør, ovner og kokere. Studier har også vist økt risiko for kreft i lymfesystmet ved arbeid i ulike deler av denne industrien $(11,12)$.

\section{FORMÅL}

Formålet med studien var å kartlegge om ansatte $\mathrm{i}$ norsk papir- og celluloseindustri hadde økt risiko for å utvikle kreft generelt, og spesielt i luftveier, fordøyelsesorganer og lymfe/bloddannende organer. Beskrivelse av kohorten, materialet og resultatene fra den foreliggende studien er diskutert i større bredde tidligere $(13,14)$.

\section{MATERIALE OG METODER}

Materialet besto av ansatte ved 11 papir- og cellulosefabrikker som hadde vært ansatt i minimum ett år i perioden 1920-1993. Til sammen utgjorde dette et materiale på 23718 menn (594 386 personår) og 4247 kvinner (108 095 personår). Med utgangspunkt i personallister fra de 11 bedriftene ble det laget en persondatabase som inneholdt fødselsdato, navn, tidspunkt 
for alle ansettelser (startdato og sluttdato) i den enkelte avdeling, inkludert spesifikke jobber de hadde hatt.

Kohorten ble koblet med data fra Kreftregisteret for å få informasjon om kreftdiagnoser, og med data fra Statistisk sentralbyrå for å få informasjon om dødsdato, dødsårsaker og eventuelt emigrasjonsdato. Kohorten ble fulgt opp med tanke på kreft, død og emigrasjon i perioden fra 1953 til utgangen av 1993. Persontid ble kalkulert for hver person fra ett år etter første ansettelse inntil død, emigrasjon eller slutten av oppfølgingstiden.

Studien var basert på en sammenligning av observert og forventet antall av nye krefttilfeller. Forventet antall ble beregnet ut fra 5-års alderspesifikk insidensrate for hvert år for hele den norske befolkning. Standard insidensrater (SIR) ble beregnet som ratioen mellom observert og forventet antall. SIR verdier med 95\% konfidensintervaller ble beregnet ved hjelp av statistikkpakken Epicure (15).

Analyser ble gjort for korttidsansatte (ansatt $<3$ år) og langtidsansatte (ansatt 3 år eller mer). For å undersøke mulige effekter av arbeidets varighet ble ansettelsestid delt inn i tre kategorier: 1-3 år, 3-9 år og 10 år eller mer. Separate analyser ble også gjort for tid siden første ansettelse; 1-14 år, 15-29 år og 30 år eller mer, som indikator på den tid som har gått fra første ansettelse og frem til kreftdiagnose. Som en indikasjon på endringer i eksponering over tid beregnet vi tidspunkt for første ansettelse i følgende kategorier: 1920-1939, 1940-1959, 1960-1974 og 1975-1993.

De ansatte ble delt inn i seks grupper i henhold til arbeidsmiljø: sulfittavdeling, sulfatavdeling, papirproduksjon, vedlikeholdsavdeling, administrasjon og andre avdelinger.

\section{RESULTATER}

I løpet av oppfølgingsperioden 1953-1993 ble det registrert 2965 nye tilfeller av kreft, 2585 blant menn og 380 blant kvinner. Hos begge kjønn er dette signifikant flere tilfeller enn ventet, når vi ser på alle kreftformer under ett.

\section{Kreftrisiko blant menn}

Tabell 1 viser observert forekomst for kort- og langtidsansatte sammenlignet med forventet antall. Hos de korttidsansatte viser resultatene for alle kreftformer under ett en signifikant økt risiko (SIR $=1,3,95 \% \mathrm{KI}$ 1,13-1,42). En signifikant økning ble også registrert for lungekreft (48 tilfeller mot forventet 31,3) og kreft i spiserøret ( 7 tilfeller mot 2,8 forventet). For alle øvrige lokalisasjoner ble det ikke observert noen signifikant økning i risiko.

Tabell 1. Observert (Obs.) antall nye krefttilfeller blant menn i norsk papir og celluloseindustri for perioden 1953-1993. Forventningsverdier (Forv.), SIR-verdier (standard insidens rate) og 95\% konfidensintervaller (95\% KI) er gitt for ansatt kortere enn tre år og ansatt 3 år eller mer.

\begin{tabular}{|c|c|c|c|c|c|c|c|c|c|}
\hline \multirow[b]{2}{*}{ Kreftform } & \multirow[b]{2}{*}{ ICD-7 kode } & \multicolumn{4}{|c|}{ Ansatt under 3 år } & \multicolumn{4}{|c|}{ Ansatt 3 år eller mer } \\
\hline & & Obs. & Forv. & SIR & $95 \% \mathrm{KI}$ & Obs. & Forv. & SIR & $95 \% \mathrm{KI}$ \\
\hline Alle kreftformer & $140-204$ & 303 & 239,4 & 1,3 & {$[1,13-1,42]$} & 2282 & 2230,2 & 1,0 & {$[0,98-1,07]$} \\
\hline Leppe & 140 & 4 & 3,1 & 1,3 & {$[0,36-3,36]$} & 37 & 30,4 & 1,2 & {$[0,86-1,68]$} \\
\hline Munnhule, svelg & $141,143-148,161$ & 12 & 8,1 & 1,5 & {$[0,77-2,60]$} & 72 & 69,5 & 1,0 & {$[0,81-1,30]$} \\
\hline Spiserør & 150 & 7 & 2,8 & 2,5 & {$[1,00-5,12]$} & 23 & 27,7 & 0,8 & {$[0,53-1,25]$} \\
\hline Magesekk & 151 & 18 & 17,9 & 1,0 & {$[0,60-1,59]$} & 173 & 195,7 & 0,9 & {$[0,76-1,03]$} \\
\hline Tykktarm & 153 & 25 & 18,1 & 1,4 & {$[0,90-2,04]$} & 204 & 174,9 & 1,2 & {$[1,02-1,34]$} \\
\hline Endetarm & 154 & 17 & 12,3 & 1,4 & {$[0,81-2,21]$} & 125 & 117,7 & 1,1 & {$[0,89-1,27]$} \\
\hline Nesehule, mellomøre & 160 & 1 & 0,8 & 1,3 & {$[0,03-7,23]$} & 6 & 7,3 & 0,8 & {$[0,30-1,79]$} \\
\hline Lunge & 162 & 48 & 31,3 & 1,5 & {$[1,13-2,03]$} & 356 & 295,7 & 1,2 & {$[1,09-1,34]$} \\
\hline Brysthinne (pleura) & 163 & 2 & 0,9 & 2,2 & {$[0,26-7,83]$} & 19 & 7,9 & 2,4 & {$[1,45-3,75]$} \\
\hline Prostata & 177 & 32 & 33,7 & 1,0 & {$[0,65-1,34]$} & 386 & 396,0 & 1,0 & {$[0,88-1,08]$} \\
\hline Testikkel & 178 & 9 & 8,2 & 1,1 & {$[0,50-2,08]$} & 23 & 32,6 & 0,7 & {$[0,45-1,06]$} \\
\hline Nyre & 180 & 12 & 9,1 & 1,3 & {$[0,68-2,31]$} & 84 & 82,5 & 1,0 & {$[0,81-1,26]$} \\
\hline Blære & 181 & 22 & 16,0 & 1,4 & {$[0,86-2,08]$} & 141 & 155,7 & 0,9 & {$[0,77-1,07]$} \\
\hline Ondartet føflekk & 190 & 16 & 11,6 & 1,4 & {$[0,79-2,24]$} & 88 & 67,8 & 1,3 & {$[1,04-1,60]$} \\
\hline Annen hudkreft & 191 & 4 & 6,0 & 0,7 & {$[0,18-1,73]$} & 66 & 59,6 & 1,1 & {$[0,86-1,41]$} \\
\hline Lymfekreft (NHL) & 202 & 7 & 9,7 & 0,7 & {$[0,29-1,48]$} & 68 & 74,8 & 0,9 & {$[0,71-1,15]$} \\
\hline Lymfekreft (HL) & 201 & 3 & 2,9 & 1,0 & {$[0,21-3,04]$} & 15 & 17,4 & 0,9 & {$[0,48-1,42]$} \\
\hline Myelomatose & 203 & 7 & 4,2 & 1,7 & {$[0,66-3,41]$} & 37 & 43,4 & 0,9 & {$[0,60-1,18]$} \\
\hline Leukemier & 204 & 9 & 6,3 & 1,4 & {$[0,65-2,71]$} & 53 & 58,9 & 0,9 & {$[0,67-1,18]$} \\
\hline Andre kreftformer & & 48 & 35,7 & 1,4 & {$[0,99-1,73]$} & 306 & 321,7 & 1,0 & {$[0,86-1,07]$} \\
\hline
\end{tabular}

NHL $=$ Non-Hodgkins lymfom

$\mathrm{HL}=$ Hodgkins lymfom

SIR $=$ Observert $/$ Forventet 
Blant langtidsansatte ble det registret 2282 tilfeller av alle kreftformer, mot forventet 2230 . SIR for kreft $\mathrm{i}$ lunge og brysthinne viste signifikant økning $(1,2,95 \%$ KI 1,09-1,34 og 2,4, 95\% KI 1,45-3,75), og økning i risiko ble også vist for kreft i tykktarm og føflekk. For kreft i lymfe og bloddannende organer ble det registrert færre tilfeller enn forventet.

Omkring 50\% av lungekrefttilfellene ble registret blant de med lengst ansettelse og lengst tid siden første ansettelse; 183 observerte tilfeller mot 140 forventet (SIR 1,3, 95\% KI 1,08-1,44) (tabell 2).

Risikoen for brysthinnekreft var også høyest blant de med lengst ansettelse og lengst tid siden første ansettelse (SIR 2,8, 95\% KI 1,38-4,96).

Økningen i tykktarmskreft viste ingen klar trend i forhold til antall år ansatt eller tid siden første ansettelse. SIR verdiene for føflekkreft viste imidlertid en økende trend med økende antall år siden første ansettelse, og signifikant økt for menn med 30 år eller mer siden første ansettelse og 10 år eller mer i ansettelsestid (SIR 1,9, 95\% KI 1,33-2,51). Dette var et uventet funn. Separate analyser for hver bedrift viste at risi- koen var spesielt høy i en av bedriftene $\mathrm{i} ø$ øtlandsområdet (ikke vist i tabell).

Videre viste resultatene at de som ble ansatt forste gang i perioden 1920-1959 hadde høyere risiko for lungekreft enn de som ble ansatt $i$ senere perioder (ikke vist $\mathrm{i}$ tabell). I avdelingsanalysene viste ansatte $i$ sulfittavdelinger signifikant økt risiko for lungekreft (SIR 1,5, 95\% KI 1,09-1,99), mens vedlikeholdsarbeidere viste signifikant økt risiko for brysthinnekreft (SIR 3,5, 95\% KI 1,29-7,62) og føflekkreft (SIR 1,7, 95\% KI 1,12-2,55) (tabell 3).

\section{Kreftrisiko blant kvinner}

Blant korttidsansatte kvinner ble det vist signifikant økt risiko for kreft i lunge (SIR 3,0, 95\% KI 1,29-5,89) og blære (SIR 3,7, 95\% KI 1,00-9,38). For de øvrige kreftformer var det observerte antall omtrent som forventet (tabell 4).

Blant langtidsansatte ble det registrert 31 tilfeller av kreft i eggstokker mot forventet 19,18 (SIR 1,62, KI 1,10-2,29). En stor andel av disse tilfellene ble diagnostisert i de yngre aldersgruppene før 55 år.

Tabell 2. Standardisert insidensrate (SIR) med 95\% konfidensintervaller (95\% KI) for ulike kreftformer blant kort- og langtidsansatte, tabulert for tid siden første ansettelse og antall år ansatt. Oppfølgingsperiode 1953-1993.

\begin{tabular}{|c|c|c|c|c|c|c|c|c|c|c|c|}
\hline \multirow[b]{3}{*}{ Kreftform } & \multirow{3}{*}{$\begin{array}{l}\text { ICD-7 } \\
\text { kode }\end{array}$} & \multirow{3}{*}{$\begin{array}{l}\text { Tid siden første } \\
\text { ansettelse (år) }\end{array}$} & \multicolumn{9}{|c|}{ Antall år ansatt } \\
\hline & & & \multicolumn{3}{|c|}{$1-3$} & \multicolumn{3}{|c|}{$3-9$} & \multicolumn{3}{|c|}{$\geq 10$} \\
\hline & & & Obs. & SIR & $95 \% \mathrm{KI}$ & Obs. & SIR & $95 \% \mathrm{KI}$ & Obs. & SIR & $95 \% \mathrm{CI}$ \\
\hline \multirow[t]{3}{*}{ Lunge } & 162 & $1-14$ & 5 & 0,6 & $(0,18-1,32)$ & 26 & 1,2 & $(0,79-1,76)$ & 12 & 0,9 & $(0,46-1,55)$ \\
\hline & & $15-29$ & 21 & 1,7 & $(1,02-2,52)$ & 29 & 1,4 & $(0,91-1,94)$ & 77 & 1,1 & $(0,83-1,31)$ \\
\hline & & $\geq 30$ & 22 & 1,8 & $(1,12-2,71)$ & 29 & 1,5 & $(0,99-2,13)$ & 183 & 1,3 & $(1,08-1,44)$ \\
\hline \multirow[t]{3}{*}{ Brysthinne } & 163 & $1-14$ & 1 & 4,4 & $(0,11-24,54)$ & 4 & 7,7 & $(2,10-19,74)$ & 1 & 3,2 & $(0,08-17,67)$ \\
\hline & & $15-29$ & 0 & - & - & 0 & - & - & 2 & 1,1 & $(0,13-3,95)$ \\
\hline & & $\geq 30$ & 1 & 2,6 & $(0,07-14,42)$ & 1 & 1,7 & $(0,04-9,35)$ & 11 & 2,8 & $(1,38-4,96)$ \\
\hline \multirow[t]{3}{*}{ Tykktarm } & 153 & $1-14$ & 8 & 1,5 & $(0,65-2,99)$ & 17 & 1,4 & $(0,81-2,22)$ & 7 & 1,0 & $(0,39-2,00)$ \\
\hline & & $15-29$ & 8 & 1,1 & $(0,47-2,15)$ & 18 & 1,4 & $(0,83-2,20)$ & 44 & 1,1 & $(0,79-1,47)$ \\
\hline & & $\geq 30$ & 10 & 1,4 & $(0,69-2,64)$ & 16 & 1,4 & $(0,81-2,31)$ & 102 & 1,1 & $(0,93-1,37)$ \\
\hline \multirow[t]{3}{*}{ Føflekk } & 190 & $1-14$ & 5 & 0,9 & $(0,29-2,07)$ & 11 & 1,2 & $(0,58-2,07)$ & 2 & 0,4 & $(0,05-1,42)$ \\
\hline & & $15-29$ & 6 & 4,2 & $(0,43-2,53)$ & 10 & 1,4 & $(0,67-2,56)$ & 20 & 1,1 & $(0,66-1,68)$ \\
\hline & & $\geq 30$ & 5 & 2,0 & $(0,64-4,60)$ & 4 & 1,0 & $(0,28-2,67)$ & 41 & 1,9 & $(1,33-2,51)$ \\
\hline
\end{tabular}

Tabell 3. Standardisert insidensrate (SIR) med 95\% konfidensintervaller ( $95 \% \mathrm{KI})$ for utvalgte kreftformer blant langtidsansatte (ansatt $\geq 3$ år) i de ulike avdelinger. Follow-up 1953-1993.

\begin{tabular}{|c|c|c|c|c|c|c|c|c|c|c|c|c|}
\hline \multirow[b]{2}{*}{ Avdeling } & \multicolumn{3}{|c|}{ Lunge (ICD-7 = 162) } & \multicolumn{3}{|c|}{ Brysthinne (ICD-7 = 163) } & \multicolumn{3}{|c|}{ Tykktarm (ICD-7 = 153) } & \multicolumn{3}{|c|}{ Føflekk $($ ICD-7 = 190) } \\
\hline & Obs. & SIR & $95 \% \mathrm{KI}$ & Obs. & SIR & $95 \% \mathrm{KI}$ & Obs. & SIR & $95 \% \mathrm{KI}$ & Obs. & SIR & $95 \% \mathrm{KI}$ \\
\hline Sulfitt & 46 & 1,5 & $(1,09-1,99)$ & 2 & 2,4 & $(0,30-8,83)$ & 23 & 1,3 & $(0,80-1,88)$ & 10 & 1,6 & $(0,78-2,97)$ \\
\hline Sulfat & 12 & 1,4 & $(0,73-2,47)$ & 1 & 4,4 & $(0,11-24,65)$ & 6 & 1,2 & $(0,45-2,65)$ & 4 & 2,3 & $(0,64-5,97)$ \\
\hline Papir & 81 & 1,2 & $(0,94-1,47)$ & 3 & 1,6 & $(0,33-4,68)$ & 44 & 1,1 & $(0,81-1,49)$ & 21 & 1,3 & $(0,78-1,93)$ \\
\hline Vedlikehold & 74 & 1,2 & $(0,93-1,48)$ & 6 & 3,5 & $(1,29-7,62)$ & 42 & 1,1 & $(0,82-1,54)$ & 25 & 1,7 & $(1,12-2,55)$ \\
\hline Administrasjon & 58 & 1,1 & $(0,82-1,40)$ & 3 & 2,0 & $(0,42-5,92)$ & 30 & 1,0 & $(0,65-1,37)$ & 19 & 1,5 & $(0,89-2,30)$ \\
\hline Andre avdelinger & 123 & 1,2 & $(0,97-1,38)$ & 6 & 2,2 & $(0,80-4,73)$ & 78 & 1,2 & $(0,97-1,53)$ & 24 & 1,1 & $(0,74-1,72)$ \\
\hline
\end{tabular}


Tabell 4. Observert (Obs.) antall nye krefttilfeller blant kvinner i norsk papir og celluloseindustri, for perioden 1953-1993. Forventningsverdier (Forv.), SIR-verdier (standard insidens rate) og 95\% konfidensintervaller (95\% KI) er gitt for ansatte kortere enn tre år og ansatte 3 år eller mer.

\begin{tabular}{|c|c|c|c|c|c|c|c|c|c|}
\hline \multirow[b]{2}{*}{ Lokalisasjon } & \multirow[b]{2}{*}{ ICD-7 kode } & \multicolumn{4}{|c|}{ Ansatt under 3 år } & \multicolumn{4}{|c|}{ Ansatt 3 år eller mer } \\
\hline & & Obs. & Forv. & SIR & $95 \% \mathrm{KI}$ & Obs. & Forv. & SIR & $95 \% \mathrm{KI}$ \\
\hline Alle kreftformer & $140-204$ & 76 & 65,6 & 1,2 & {$[0,91-1,45]$} & 304 & 256,8 & 1,2 & {$[1,06-1,32]$} \\
\hline Magesekk & 151 & 2 & 2,1 & 0,9 & {$[0,11-3,41]$} & 16 & 11,2 & 1,4 & {$[0,82-2,33]$} \\
\hline Tykktarm & 153 & 6 & 4,6 & 1,3 & {$[0,48-2,86]$} & 23 & 21,6 & 1,1 & {$[0,68-1,60]$} \\
\hline Endetarm & 154 & 2 & 2,2 & 0,9 & {$[0,11-3,26]$} & 12 & 10,2 & 1,2 & {$[0,61-2,05]$} \\
\hline Lunge & 162 & 8 & 2,7 & 3,0 & {$[1,29-5,89]$} & 14 & 10,9 & 1,4 & {$[0,70-2,16]$} \\
\hline Brysthinne & 163 & 0 & 0,0 & - & - & 0 & 0,1 & - & - \\
\hline Bryst & 170 & 22 & 16,0 & 1,4 & {$[0,86-2,08]$} & 70 & 60,2 & 1,2 & {$[0,91-1,47]$} \\
\hline Livmorhals (cervix) & 171 & 5 & 6,5 & 0,8 & {$[0,25-1,79]$} & 24 & 20,5 & 1,2 & {$[0,75-1,74]$} \\
\hline Eggstokker (ovarier) & 175 & 6 & 5,2 & 1,2 & {$[0,42-2,50]$} & 31 & 19,2 & 1,6 & {$[1,10-2,29]$} \\
\hline Nyre & 180 & 2 & 1,2 & 1,6 & {$[0,19-2,82]$} & 8 & 5,7 & 1,4 & {$[0,61-2,79]$} \\
\hline Blære & 181 & 4 & 1,1 & 3,7 & {$[1,00-9,38]$} & 1 & 5,3 & 0,2 & {$[0,00-1,04]$} \\
\hline Ondartet føflekk & 190 & 7 & 4,3 & 1,6 & {$[0,65-3,34]$} & 9 & 12,3 & 0,7 & {$[0,33-1,38]$} \\
\hline Annen hudkreft & 191 & 0 & 0,9 & - & - & 7 & 4,3 & 1,6 & {$[0,66-3,39]$} \\
\hline Lymfekreft (NHL) & 202 & 1 & 2,0 & 0,5 & {$[0,01-2,86]$} & 6 & 7,5 & 0,8 & {$[0,30-1,75]$} \\
\hline Lymfekreft (HL) & 201 & 0 & 0,5 & - & - & 1 & 1,6 & 0,6 & {$[0,02-3,59]$} \\
\hline Myelomatose & 203 & 3 & 0,7 & 4,4 & {$[0,91-12,86]$} & 4 & 3,6 & 1,1 & {$[0,30-2,82]$} \\
\hline Leukemier & 204 & 0 & 1,1 & - & - & 2 & 4,8 & 0,4 & {$[0,05-1,51]$} \\
\hline Andre kreftformer & & 8 & 14,4 & 0,6 & {$[0,24-1,10]$} & 76 & 57,5 & 1,3 & {$[1,04-1,65]$} \\
\hline
\end{tabular}

NHL $=$ Non-Hodgkins lymfom

$\mathrm{HL}=$ Hodgkins lymfom

$\mathrm{SIR}=$ Observert/Forventet

Avdelingsanalysene viste at kvinner i papiravdelinger hadde den største risikoen med 18 observerte tilfeller (SIR 2,1, 95\% KI 1,26-3,36) (ikke vist i tabell). Gruppen for andre lokalisasjoner viste en signifikant forhøyet risiko (tabell 4), men separate analyser viste ingen risikoøkning for spesifikke kreftformer.

Risiko for eggstokkreft relatert til tid siden første ansettelse viste SIR verdier på 3,8, 2,3 og 1,8 i de tre oppfølgingsperiodene. Signifikant økt risiko ble observert for de med 1-14 år siden første ansettelse, men basert på bare 4 tilfeller. Risikoen var videre høyest for de som ble ansatt første gang i perioden 1940-1959 (ikke vist i tabeller). Resultatene viste ingen klar trend i forhold til ansettelsestid.

\section{DISKUSJON}

Studien viste en signifikant økt risiko for kreft i lunge, brysthinne, tykktarm og føflekk blant menn. Blant kvinnelige ansatte var risikoen for eggstokkreft signifikant økt.

$\varnothing \mathrm{kt}$ lungekreftrisiko er i overenstemmelse med resultater fra studier $i$ andre land $(5,16,17)$. I den foreliggende studien hadde vi ingen tilgjengelige røykedata, men ved hjelp av Axelsons metode (18) estimerte vi at ca. $23 \%$ av økningen i risiko kan forklares med røykevaner. Flesteparten av bedriftene som er inkludert i vår studie ligger imidlertid i rurale områder hvor røykeprevalensen er lavere enn i den øvrige befolkningen, og derfor kan det tenkes at en høyere lungekreftrisiko kan skyldes også andre faktorer enn røyking.

Tabell 2 viser at risikoen for lungekreft øker med tid som har gått siden første ansettelse. Dette stemmer overens med antakelsen om at utviklingstiden for yrkesbetinget lungekreft er lang. Videre var risikoen høyest blant de som var ansatt lengst tilbake i tid, noe som kan indikere at arbeidsmiljøforholdene har endret seg.

Asbest har vært mye brukt i flere avdelinger i papir- og celluloseindustrien. Den økte risikoen for brysthinnekreft som ble funnet $i$ vår studie, er også rapportert av andre $(19,20)$. Som for lungekreft, var risikoen størst blant de med lengst tid siden første ansettelse, som stemmer med at utviklingstiden for brysthinnekreft er lang. Videre viste vedlikeholdsarbeidere den høyeste risikoen, nok en indikasjon på at økningen kan være forårsaket av asbesteksponering. Studien viste ingen økning i risiko for kreft i lymfe- og bloddannende organer, som er vist av andre.

Økningen i forekomsten av føflekkreft var et uventet funn. Den sterkeste risikofaktor for denne kreftform, er som kjent soleksponering (21). Geografiske forskjeller i insidensen av føflekkreft i Norge er betydelig (22), og nærmere analyser av våre data viste at risikoen var høyest for en bedrift lokalisert i de sørøstlige deler av Norge. Regionale forskjeller i UVstråling er derfor en mer sannsynlig forklaring på økningen enn eksponeringer i arbeidsmiljøet. 
Den økte risikoen for kreft i eggstokker var også et uventet funn, og er ikke tidligere vist blant ansatte $i$ papir- og celluloseindustrien $(5,9)$. Liknende observasjoner er imidlertid gjort $\mathrm{i}$ industrier med tilsvarende eksponeringer. En finsk rapport viste økt risiko for kreft i eggstokker blant ansatte i kjemiske prosesser/ papirproduksjon (23). En russisk studie fant signifikant økt risiko blant bokbindere (24), og en eksperimentell studie gjort på hamster viste at avfallsprodukter fra papir- og celluloseindustrien ga genskader (søster kromatide bytte) i celler fra eggstokker (25).

Sammenhengen mellom eggstokkreft og yrke/ miljøbetingete faktorer er lite kjent, bortsett fra noen studier som har sett på sammenhengen med eksponering for talkum og asbest. Assosiasjon mellom kreft $i$ eggstokker og asbesteksponering ble belyst i to dødelighetsstudier hos kvinner som arbeidet med produksjon av gassmasker før og under andre verdenskrig. De viste forhøyet risiko blant crocidolitteksponerte (26) og asbesteksponerte generelt (27). I en finsk studie ble det funnet indikasjoner på at høye asbesteksponeringer ga økt risiko for eggstokkreft (28). Det er kjent at relativt store mengder asbest har vært brukt $\mathrm{i}$ norsk papir- og celluloseindustri, men i hvilken grad kvinner også har vært eksponert er mer usikkert, men det er verdt å merke seg at svært lave eksponeringer ved for eksempel såkalt "household exposure" er vist å kunne gi brysthinnekreft blant kvinner (29-31). Asbestfibre er også påvist i vev fra eggstokker (32).

Mistanken om sammenhengen mellom talkumeksponering og eggstokkreft kan knyttes til det kjemiske forholdet mellom talkum og asbest, at asbest forårsaker pleurale og peritoneale mesotheliomer, at det ofte er histologisk likhet mellom epiteliale typer av eggstokkreft og mesotheliomer, og at talkumen har mulighet til å deponeres i eggstokker (33). Talkum har i lang tid vært benyttet både til kosmetisk bruk og $\mathrm{i}$ industriell sammenheng (bl.a. papir, tekstil og gummiindustri).
Noen studier har vist at kvinner som har vært eksponert for talkum på ytre genitalia, via pudderbruk, underlivsspray og på bind, hadde økt risiko for eggstokkreft $(34,35)$. I norsk papir- og celluloseindustri vet vi at det har vært brukt talkum i papirmassen for å unngå harpiksflekker i papiret. Kvinner ansatt i papiravdelingen kan dermed ha vært eksponert for talkum i papirstøvet som dannes under kutting og pakking av papiret.

\section{Videre hypoteser og oppfolgingsstudier}

Den økte risikoen for eggstokkreft var som nevnt et uventet funn. Dette er en studie hvor det er beregnet mange risikoestimater og enkeltstående signifikante funn bør derfor tolkes med forsiktighet. Selv om antallet tilfeller imidlertid er lite og trender i eksponeringsindikatorer er svak, kan vi ikke utelukke at risikoen er yrkesrelatert. Studien inkluderer et stort antall kvinner som har hatt lik yrkeseksponering og har utviklet samme kreftsykdom. Få studier har tidligere kunnet rapportere gode yrkesepidemiologiske data for kvinner, fordi de kom senere inn i industrien enn menn, og de har vært i mindretall i forhold til mannlige ansatte. Internasjonalt er kvinner ofte ikke inkludert fordi man har for få og dårlige opplysninger, spesielt hva angår eksponeringsdata.

Når vi videre vet at eggstokkreft rammer ca. 480 kvinner hvert år, og er en sykdom med relativt dårlig prognose og hvor årsaksfaktorer er lite kjent, ser vi det som en utfordring å følge opp dette funn. Vi har derfor igangsatt en intervju-undersøkelse for å se på yrkeseksponering og risiko for eggstokkreft blant kvinner i norsk papir- og celluloseindustri - en "nested casecontrol" studie. Videre planlegger vi, i samarbeid med avdeling for patologi, DNR og biologisk institutt UiO, en studie for å se på deponering av talkum/asbestfibre i vev fra eggstokker - en histologisk snittstudie.

\section{REFERANSER}

1. Rix BA, Villadsen E, Lynge E. Cancer incidence of sulfite pulp workers in Denmark. Scand J Work Environ Health 1997; 23: 458-61.

2. Andersson E, Nilsson T, Persson B, Wingren G, Torén K. Mortality from asthma and cancer among sulfite mill workers. Scand J Work Environ Health 1998; 24: 12-7.

3. Matanoski GM, Kanchanaraksa S, Lees PSJ, Tao Xu-Guang, Royall R, Francis M, et al. Industry-wide study of mortality of pulp and paper mill workers. Am J Ind Med 1998; 33: 354-65.

4. Jäppinen P, Pukkala E. Cancer incidence among pulp and paper workers exposed to organic chlorinated compounds formed during chlorine pulp bleaching. Scand J Work Environ Health 1991; 17: 356-9.

5. Jäppinen P, Hakulinen T, Pukkala E, Tola S, Kurppa K. Cancer incidence of workers in the Finnish pulp and paper industry. Scand J Work Environ Health 1987; 13: 197-202.

6. Torén K, Sällsten G, Järvholm B. Mortality from asthma, chronic obstructive pulmonary disease, respiratory system cancer, and stomach cancer among paper mill workers: a case-referent study. Am J Ind Med 1991; 19: 729-37. 
7. Siemiatycki J, Richardson L, Gérin M, Goldberg M, Dewar R, Désy M, et al. Associations between several sites of cancer and nine organic dusts: results from an hypothesis-generating case-control study in Montreal, 1979-1983. Am J Epidemiol 1986; 123: 235-49.

8. Robinson CF, Waxweiler RJ, Fowler DP. Mortality among production workers in pulp and paper mills. Scand $J$ Work Environ Health 1986; 12: 552-60.

9. Coggon D, Wield G, Pannett B, Campbell L, Boffetta P. Mortality in employees of a Scottish paper mill. Am J Ind Med 1997; 32: 535-9.

10. Szadkowska-Stañczyk I, Boffetta P, Wilczyñska U, Szeszenia-Dabrowska N, Szymczak W. Cancer mortality among pulp and paper workers in Poland. A cohort study. Int J Occup Med Environ Health 1997; 10: 19-29.

11. Milham S Jr. Neoplasia in the wood and pulp industry. Ann N Y Acad Sci 1976; 271: 294-300.

12. Schwartz E. A proportionate mortality ratio analysis of pulp and paper mill workers in New Hampshire. $B r J$ Ind Med 1988; 45: 234-8.

13. Langseth $\mathrm{H}$, Andersen Aa. Cancer incidence among women in the Norwegian pulp and paper industry. Am $J$ Ind Med 1999; 36: 108-13.

14. Langseth $\mathrm{H}$, Andersen Aa. Cancer incidence among male pulp and paper workers in Norway. Scand J Work Environ Health 2000; 26 (2): 99-105.

15. Preston DL, Lubin JH, Pierce DA, McConney ME. Epicure. Seattle (WA): Hirosoft International Corporation, 1993.

16. Menck HR, Henderson BE. Occupational differences in rates of lung cancer. J Occup Med 1976; 18: 797-801.

17. Solet D, Zoloth SR, Sullivan C, Jewett J, Michaels DM. Patterns of mortality in pulp and paper workers. $J$ Occup Med 1989; 31: 627-30.

18. Axelson O. Aspects on confounding in occupational health epidemiology. Scand J Work Environ Health 1978; 4: 98-102.

19. Malker HSR, McLaughlin JK, Malker BK, Stone BJ, Weiner JA, Erickson JLE, et al. Occupational risks for pleural mesothelioma in Sweden, 1961-79. JNCI 1985; 74: 61-6.

20. Band PR, Le ND, Fang R, Threlfall WJ, Astrakianakis G, Anderson JTL, et al. Cohort mortality study of pulp and paper mill workers in British Columbia, Canada. Am J Epidemiol 1997; 146: 186-94.

21. Winther JF, Ulbak K, Dreyer L, Pukkala E, Østerlind A. Radiation. In: Avoidable cancers in the Nordic countries. Acta Pathol Microbiol Immunol Scand 1997; 105 suppl 76: 83-99.

22. Cancer Registry of Norway. Cancer in Norway 1995. Oslo: Cancer Registry of Norway, 1995.

23. Pukkala E. Cancer risk by social class and occupation. A survey of 109,000 cancer cases among Finns of working age. In: Wahrendorf J, ed. Contributions to epidemiology and biostatistics, Vol. 7. Tampere, 1995: 236-8.

24. Bulbulyan MA, et al. Cancer mortality among women in the Russian printing industry. Am J Ind Med 1999; 36: 166-71.

25. DeMarini DM, Brusick DJ, Lewtas J. Use of limited protocols to evaluate the genotoxicity of hazardous wastes in mammalian cell assays: comparison to Salmonella. J Toxicol Environ Health 1987; 22: 225-39.

26. Acheson ED, Gardner MJ, Pippard EC, Grime LP. Mortality of two groups of women who manufactured gas masks from chrysotile and crocidolite asbestos: a 40-year follow-up. Br J Ind Med 1982; 39: 344-8.

27. Wignall BK, Fox AJ. Mortality of female gas mask assemblers. Br J Ind Med 1982; 39: 34-8.

28. Vasama-Neuvonen K, et al. Ovarian cancer and occupational exposures in Finland. Am J Ind Med 1999; 36: 83-9.

29. Kane MJ, et al. Malignant mesotheliomas in young adults. Cancer 1999; 65: 1449-55.

30. Dodoli D, et al. Environmental household exposures to asbestos and occurrence of pleural mesothelioma. $\mathrm{Am}$ J Ind Med 1992; 21: 681-7.

31. Schneider J, et al. Pleural mesothelioma and household asbestos exposure. Rev Environ Health 1996; 11: 65-70.

32. Heller DS, Gordon RE, Westhoff C, Gerber S. Asbestos exposure and ovarian fiber burden. Am J Ind Med 1996; 29: 435-9.

33. Cramer DW, et al. Ovarian cancer and talc. A case-control study. Cancer 1982; 50: 372-6.

34. Chang S, Risch HA. Perineal talc exposure and risk of ovarian carcinoma. Cancer 1997; 79: 2396-401.

35. Cook LS, et al. Perineal powder exposure and the risk of ovarian cancer. Am J Epidemiol 1997; 145: 459-65. 